\title{
Karakterisasi Morfologi Permukaan Lapisan Tipis Porphyrin Alam Hasil Deposisi Spin Coating dengan Atomic Force Mircroscopy
}

\author{
Elvira Freditia Fonita, ${ }^{1, *}$ Elly Fatmawati, ${ }^{1}$ Defi Sulistiyana, ${ }^{1}$ Utari, ${ }^{1}$ Budi Purnama, ${ }^{1, \dagger}$ dan Kamsul Abraha ${ }^{2}$ \\ ${ }^{1}$ Jurusan Fisika FMIPA, Universitas Sebelas Maret, Jl. Ir. Sutami 36A, Kentingan, Surakarta 57126 \\ ${ }^{2}$ Jurusan Fisika FMIPA, Universitas Gadjah Mada, Bulaksumur BLS 21, Yogyakarta 55281
}

Intisari

\begin{abstract}
Sintesis dan fabrikasi lapisan tipis berbasis nanopartikel porphyrin alam dilaporkan pada makalah ini. Larutan porphyrin alam disintesis melalui proses permurnian dengan teknik kolom kromatografi kemudian ditumbuhkan menjadi lapisan di atas substrat $\mathrm{Cu}$ dengan metode spin coating. Hasil pengamatan dengan atomic force microscopy menegaskan bahwa lapisan tipis tersusun dari struktur islands dengan dimensi nano meter orde. Dimensi lateral lapisan tipis dengan $\mathrm{N}=3$ menunjukkan struktur island sebesar $800 \mathrm{~nm}$ yang lebih kecil dibandingkan sampel $\mathrm{N}=5$ yaitu $1200 \mathrm{~nm}$. Pengamatan lebih detail untuk skala scan lebih kecil menegaskan bahwa dimensi islands yang besar merupakan himpunan islands kecil-kecil membentuk suatu ikatan tertentu. Akhirnya, jika satu unit islands merupakan sebuah molekul, maka island-island tersebut berinteraksi membentuk suatu supra-molekuler.
\end{abstract}

\begin{abstract}
Synthesis and fabrication of nanoparticle-based thin layer of natural porphyrin is reported in this paper. Porphyrin solution was synthesized by using a process of natural purification with column chromatography techniques. It was then grown into a thin film an a $\mathrm{Cu}$ substrate by spin coating method. Observations with atomic force microscopy confirmed that the thin layer structure is with the composition of islands with dimensions of the order of nano-meters. The lateral dimensions of the thin layer with $\mathrm{N}=3$ showed the structure of the island of $800 \mathrm{~nm}$ which is smaller than the sample of $\mathrm{N}=5$ is $1200 \mathrm{~nm}$. Moreover, an observation of smaller-scale scan confirmed that the islands which are larger dimension are composed of small islands with a certain bond. Finally, if the one unit of island is a molecule, the islands may interact to form a supra-molecular.
\end{abstract}

KATA KUNCI: natural porphyrin, thin films, spin coating, surface morphology

\section{PENDAHULUAN}

Beberapa tahun terakhir ini divais elektronika organik telah banyak dikaji oleh peneliti di dunia. Elektronika organik muncul sebagai bidang yang dinamis dalam hal penelitian dan pengembangan mencakup ilmu kimia, fisika dan teknologi [1]. Aplikasi divais elektronika organik ini, diantaranya sebagai sel surya organik dalam DSSC (Dye Sentized Solar Cell), fotodetektor dan dioda organik. Bahkan dewasa ini juga dikembangkan divais elektronika organik OLED's (Organic Light Emitting Diodes) [2], memori optik, terapi fotodinamik, 3D microfabrication dan mikroskop fluorosence [3].

Salah satu material organik yang saat ini banyak dikaji potensinya sebagai material elektronika adalah porphyrin [4]. Secara kimiawi porphyrin memiliki sifat biochemical dan photo-catalytic-electro yang unggul luar biasa. Material ini

\footnotetext{
*E-MAIL: dtya92elvira@gmail.com
}

†E-MAIL: bpurnama@mipa.uns.ac.id banyak digunakan dalam proses penyusunan monolayers dan thin film [5] dengan rentang energi gap kecil yaitu 0-2 eV [6]. Sehingga karakteristik menarik ini membuka potensi untuk aplikasi divais elektronika berbasis bahan organik.

Dalam perkembangannya, photochemistry porphyrin menjadi hal yang menarik perhatian para peneliti karena terkait dengan stabilitas dan aktivitas listriknya. Ditinjau dari ilmu bahan, ukuran dari partikel (molekul) porphyrin menentukan karakteristik material terlebih dalam ukuran nanometer size partikel.

Pada eksperimen ini, nanopartikel porphyrin alam disintesis melalui proses isolasi dan kromatografi. Selanjutnya larutan porphyrin ditumbuhkan menjadi lapisan tipis dengan metode spin coating. Karakteristik morfologi permukaan porphyrin selanjutnya dikarakterisasi dengan AFM (Atomic Force Microscopy). 


\section{METODE EKSPERIMEN}

\section{Preparasi larutan porphyrin alam}

Nanopartikel porphyrin alam difabrikasi melalui tahapan ekstraksi, evaporasi dan kromatografi. Porphyrin alam yang digunakan adalah hasil ekstraksi algae spirulina $s p$ di pusat pengembangan pakan ternak Jepara. Tahap yang pertama adalah preparasi larutan ekstraksi porphyrin. Pelarut yang digunakan pada penyediaan larutan porphyrin ini adalah acetone pure analysis dari Merck. Larutan porphyrin diperoleh dengan mencampurkan serbuk porphyrin alam dengan pelarut, dengan komposisi 1 : 5 (1 gram serbuk porphyrin alam dicampurkan dengan $5 \mathrm{ml}$ acetone). Larutan sampel tersebut diaduk menggunakan magnetic stirrer dengan kecepatan putar 2000 rpm selama 1 jam. Prosedur kemudian adalah penyaringan partikel terlarut dengan menggunakan kertas Whatmann no 40. Dengan kertas saring tersebut ukuran partikel lebih kecil dari $8 \mu$ m dapat melewati kertas saring. Penyaringan dilakukan dua kali dengan kertas saring sama guna memastikan penyaringan sudah benar.

Setelah diperoleh larutan hasil ekstraksi, prosedur selanjutnya evaporasi, proses memisahkan partikel terlarut yaitu partikel porphyrin alam hasil ekstraksi dengan pelarutnya. Evaporator merk BUCHI dilengkapi sistem pompa vacuum diafragma adalah peralatan yang dipakai dalam proses ini. Penggunaan sistem pompa diafragma tidak memakai oli silicon pada proses pem-vacuum-an sehingga kontaminasi larutan dengan oli silicon yang biasa dipakai pada sistem evaporasi konvensional dapat dihindarkan. Kondisi operasional proses evaporasi dapat dijelaskan sebagai berikut. Temperatur bak diatur $50^{\circ} \mathrm{C}$ mengingat pelarut yang dipakai adalah acetone. Tekanan glass reactor vacuum diatur dengan menggunakan valve pompa rotary sehingga menunjukkan nilai sebesar 550 mbar, sedangkan kecepatan rotasi glass adalah $4 \mathrm{rpm}$. Glass tabung destilasi dialiri air dingin selama proses evaporasi berlangsung. Proses evaporasi berlangsung kurang lebih selama 3 jam yaitu hingga pelarut acetone benar-benar menguap keseluhan dari larutan ekstraksi.

Tahapan prosedur selanjutnya adalah kromatografi. Kromatografi digunakan untuk permurnian lebih lanjut partikel terlarut dalam larutan. Secara umum prosedur ini adalah memisahkan komponen-komponen pada larutan dengan cara mengalirkan larutan pada suatu kolom kromatografi. Di dalam kolom terdapat bahan yang berfungsi sebagai fase diam yaitu silica gel (ukuran butiran $\approx 30 \mu \mathrm{m}$ ) dengan N-heksan sebagai pelarut. Sedangkan larutan porphyrin berperan sebagai fase bergerak. Sebelum proses kromatografi dilakukan, harus sudah dipastikan bahwa silica gel sudah mengisi secara penuh glass destilasi kolom kromatografi. Gelembung udara sebagai indikasi keberadaan rongga udara harus dipastikan sudah tidak ada. Selanjutnya, larutan porphyrin dimasukkan ke dalam kolom dan bergerak turun melewati porositas silica gel akibat grafitasi. Mengingat N-heksan inert dengan larutan porphyrin, maka N-heksan dapat ditambahkan ke dalam kolom kromatografi sebagai elemen pendorong fraksi bergerak yaitu larutan porphyrin. Untuk mempercepat gerak turun, kolom kromatografi dilengkapi pompa udara. Selama gerak turun melewati fase diam silica gel, komponenkomponen fase bergerak dapat dipisahkan. Akhirnya, larutan nano partikel porphyrin hasil kromatografi ini telah siap ditumbuhkan di atas substrat sebagai lapisan tipis porphyrin alam.

\section{Penumbuhan lapisan tipis dan karakterisasi}

Pada tahap ini, larutan porphyrin akan ditumbuhkan di atas substrat PCB (Printed Circuit Board). Sebelumnya substrat PCB dibersihkan terlebih dahulu dengan beberapa langkah sebagai berikut. Langkah pertama adalah membersihkan permukaan substrat dari lemak dan minyak akibat bersentuhan dengan jari dengan menggunakan acetone. Selanjutnya substrat dimasukan alkohol 99\% serta dibersihkan menggunakan ultrasonic cleaner di selama 10 menit. Prosedur ini diulang 2 kali untuk menyakinkan bahwa permukaan substrate sudah bersih. Setelah bersih, substrat diangkat dan dibiarkan sampai kering di udara bebas. Substrate PCB ini selanjutnya siap digunakan.

Penumbuhan lapisan tipis porphyrin alam dilakukan dengan menggunakan metode spin coating pada keadaan atmosfir. Proses deposisi spin coating dilakukan dengan dua step kecepatan putar yaitu mula-mula kecepatan putar $\omega=500$ rpm selama 5 sekon dilanjutkan $\omega=2500$ rpm selama 20 sekon. Proses pengeringan melalui post heating dilakukan dengan menggunakan hot plate di keadaan atmosfer. Temperatur post heating adalah sebesar $50^{\circ} \mathrm{C}$ selama 60 sekon. Untuk memperoleh modifikasi nano scale struktur permukaan lapisan tipis porphyrin alam, sampel dimodifikasi dengan perulangan jumlah lapisan $\mathrm{N}$ yaitu $\mathrm{N}=3$ dan $\mathrm{N}=5$. Jumlah perulangan $\mathrm{N}>5$, perkiraan ketebalan pada penelitian sebelumnya sudah melebih $1 \mu \mathrm{m}$ sehingga tidak menarik dikaji dari aspek pembentukan nano strukturalnya. Akhirnya, nano structural morfologi permukaan sampel dikarakterisasi dengan menggunakan AFM (atomic force microscopy).

\section{HASIL DAN PEMBAHASAN}

Gambar 1 memperlihatkan morfologi permukaan lapisan tipis porphyrin hasil scan AFM berdimensi $30 \mu \mathrm{m} \times 30 \mu \mathrm{m}$ untuk jumlah perulangan lapisan $\mathrm{N}=3$ dan $\mathrm{N}=5$.

Teramati dengan jelas dari gambar bahwa morfologi permukaan $\mathrm{N}=3$ lebih tidak teratur dibandingkan $\mathrm{N}=5$. Kenyataan ini menunjukkan bahwa proses pembentukan lapisan tipis sesuai dengan kaidah nukleasi island dilanjutkan dengan difusi antar islands menuju lapisan tipis kontinue. Gradasi antara lapisan teratas dan dibawahnya tidak teramati. Hal ini memperlihatkan bahwa distribusi partikel merata ke seluruhan permukaan substrat. Sebaran pembentukan island besar dan kecil disinyalir akibat distribusi ukuran partikel yang sangat lebar mengingat kertas saring yang digunakan memberi peluang partikel hingga ukuran $8 \mu \mathrm{m}$ lolos saringan. Dari Gambar 1 terlihat bagian gelap mengilustrasikan daerah lebih rendah atau daerah dasar sedangkan bagian yang lebih terang mengilustrasikan daerah lebih tinggi dibandingkan sekitarnya. 


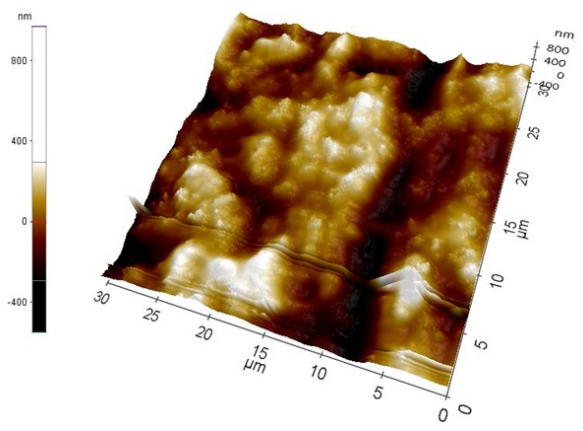

(a) variasi ketebalan 3 lapis

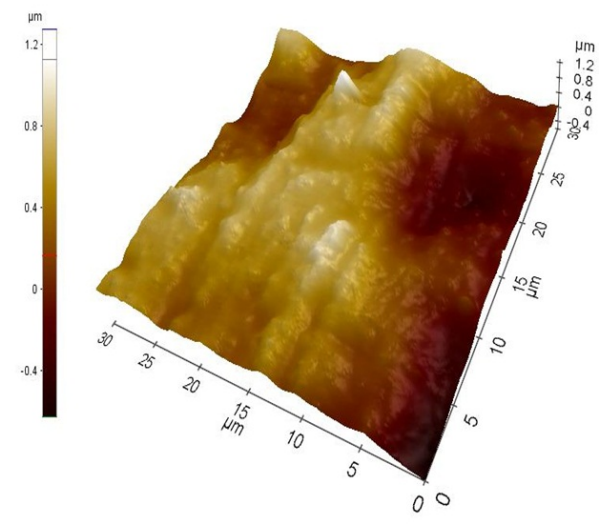

(b) variasi ketebalan 5 lapis

Gambar 1: Morfologi AFM 3D $(30 \times 30) \mu \mathrm{m}$.

Tinggi maksimum island untuk porphyrin $\mathrm{N}=3$ berkisar sekitar $300 \mathrm{~nm}$. Sedangkan lapisan tipis porphyrin $\mathrm{N}=5$ ketinggian maksimumnya adalah $900 \mathrm{~nm}$. Hasil yang diperoleh disini adalah realistis, dapat dijelaskan bahwa dengan kenaikan $\mathrm{N}$, island-island yang terbentuk belakangan mengisi ruang antara pada proses deposisi sebelumnya. Selanjutnya, permukaan lapisan tipis teramati lebih datar seperti lapisan tipis kontinue. Terlebih dengan perlakuan panas pada saat penumbuhan lapisan porphyrin.

Hasil ini dipertegas kurva histogram kedua sampel lapisan tipis yang ditunjukkan pada Gambar 2. Ketika sampel masih tipis yaitu $\mathrm{N}=3$, lebar island menduduki pada posisinya sekitar $800 \mathrm{~nm}$ dengan membentuk distribusi normal. Tipikal kemiringan pada titik tertinggi dan dasar adalah $8^{\circ}$. Hasil ini memberikan roughness permukaan lapisan tipis $\mathrm{N}=3$ cukup runcing. Sedangkan untuk lapisan tipis porphyrin alam dengan $\mathrm{N}=5$, bentangan lebar island hingga $1200 \mathrm{~nm}$. Distribusi normal sudah tidak teramati lagi mengingat partikel yang terdeposisi berikutnya mengisi ruang kosong antara island yang memberikan profil plateau seperti Gambar 2(b). Daerah plateau ini pada scan dengan jangkauan lebar yaitu $30 \mu \mathrm{m} \times 30 \mu \mathrm{m}$ teramati seperti halnya lapisan tipis kontinu.

Untuk mengetahui lebih detail struktur morfologi permukaan lapisan tipis porphyrin alam $\mathrm{N}=5$, jangkauan scan AFM diperkecil menjadi $1 \mu \mathrm{m} \times 1 \mu \mathrm{m}$ seperti yang diperlihatkan pada Gambar 3. Dari gambar terlihat bahwa permukaan datar permukaan lapisan tipis sejatinya bukanlah

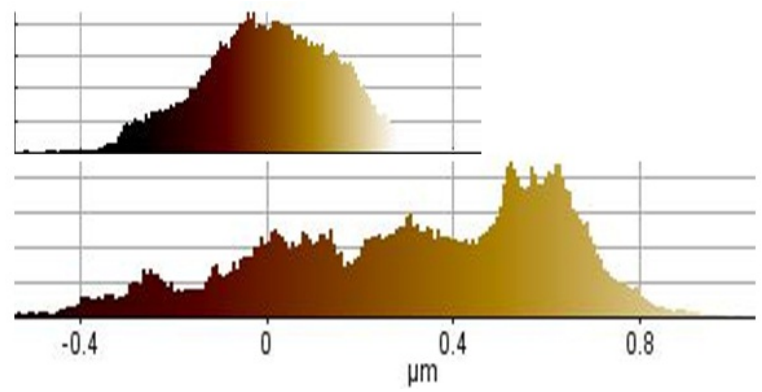

Gambar 2: Histogram tingkat kerataan (roughness) permukaan lapisan tipis porphyrin alam $\mathrm{N}=3$ (atas) dan $\mathrm{N}=5$ (bawah).

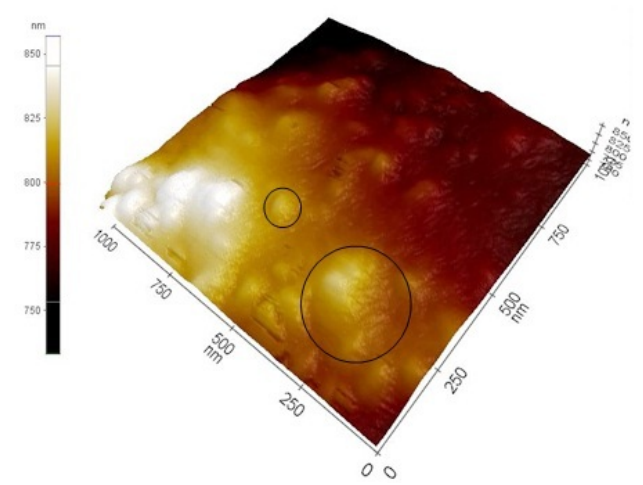

Gambar 3: Morfologi permukaan lapisan tipis porphyrin alam untuk scan range AFM 3D dimensi $1 \mu \mathrm{m} \times 1 \mu \mathrm{m}, \mathrm{N}=5$.

lapisan tipis continue. Namun merupakan gabungan nanopartikel yang mengisi dua island yang terlebih dahulu terbentuk sehingga jarak antara island semakin pendek. Ukuran diameter island tersebar antara $50 \mathrm{~nm}$ hingga $350 \mathrm{~nm}$. Island yang terbentuk seperti tersusun dari molekukl-molekul lebih kecil. Island yang didiskusikan ini disinyalir merupakan supra molekuler dari porphyrin alam. Hasil ini sesuai dengan penelitian yang telah dipublikasikan sebelumnya [7]. Akhirnya, penelitian ini menegaskan bahwa nano partikel porphyrin alam telah berhasil diperoleh.

\section{SIMPULAN}

Sintesis dan fabrikasi lapisan tipis berbasis nanopartikel porphyrin alam telah berhasil dilakukan. Larutan porphyrin alam disintesis melalui proses permurnian dengan teknik kolom kromatografi kemudian ditumbuhkan menjadi lapisan di atas substrat $\mathrm{Cu}$ dengan metode spin coating. Hasil eksperimen memperlihatkan bahwa struktur islands dengan dimensi nano meter orde terbentuk baik untuk lapisan tipis $\mathrm{N}=3$ maupun $\mathrm{N}=5$. Lapisan tipis dengan $\mathrm{N}=3$ menunjukkan dimensi lateral island sebesar $800 \mathrm{~nm}$ lebih kecil dibandingkan sampel N = 5 yaitu $1200 \mathrm{~nm}$. Selebihnya, sampel lapisan tipis porphyrin alam dengan $\mathrm{N}=3$ memperlihatkan selisih posisi tertinggi-terendah adalah $300 \mathrm{~nm}$. Sedangkan untuk N = 5 sebesar $1000 \mathrm{~nm}$. Pengamatan lebih detail untuk skala 
scan lebih kecil menegaskan bahwa dimensi islands yang besar merupakan himpunan islands kecil-kecil membentuk suatu ikatan tertentu. Jika satu unit islands merupakan sebuah molekul, maka islands tersebut berinteraksi membentuk suatu supra-molekuler.
[1] L.S. Hung, and C.H. Chen, J. Mater. Sci. Eng. R 39, 143-222 (2002).

[2] C.G. Greenham, and Tiwari Sanjay, J. Opt Quant. Electron, 41, 69-89 (2009).

[3] H. Jonathan, and K. Darius, J. Phys. Chem. B, 108, 12016-12023 (2004).
[4] M. Bernien, et al., Physical Review B 76, 214406 (2007)

[5] G. Xianchang, et al., Journal American Chemical Society $\mathbf{1 2 4}$ 14290-14291 (2002).

[6] Utari, et al., Advanced Materials Research, 896, 187-191 (2014).

[7] J.M. Alexander, and E.T. Robert, Elsevier, 34, 273-299 (2004). 